\title{
Novel approach in the evaluation of flap failure using near infrared spectroscopy and imaging
}

\author{
Badr M Abdulrauf MB ChB ${ }^{1}$, Miroslaw F Stranc MD ${ }^{1}$, Michael G Sowa $\mathrm{PhD}^{2}$, \\ Shelley L Germscheid RLATR ${ }^{2}$, Henry H Mantsch $\mathrm{PhD}^{2}$ \\ ${ }^{I}$ The Section of Plastic Surgery, University of Manitoba; and ${ }^{2}$ The National Research Council, \\ Winnipeg, Manitoba
}

BM Abdulrauf, MF Stranc, MG Sowa, SL Germscheid, HH Mantsch. Novel approach in the evaluation of flap failure
using near infrared spectroscopy and imaging. Can J Plast Surg 2000;8(2):68-72.

Methods of tissue viability assessment should be classified into those that measure blood flow and those that monitor tissue metabolism. The problem with measuring blood flow is that it can be misleading due to the phenomenon of arteriovenous shunting. Near infrared (NIR) spectroscopy is capable of identifying certain molecules in the tissues. In this study, using the reverse McFarlane rat skin flap as a model, oxygen delivery to the tissue along the flap was demonstrated in the form of a spectrum. This was achieved by using the differential absorption of oxy- and deoxyhemoglobin between wavelengths of $650 \mathrm{~nm}$ and $900 \mathrm{~nm}$. NIR imaging works on a similar principle, but an oxygen saturation image is obtained, with the darkest area indicating the most deoxygenated area of the flap and vice versa. There were two types of studies done.

In the chronic study $(\mathrm{n}=10)$, NIR spectroscopy was done on the intact skin preoperatively for three days and then after elevation of the flap at various sites for three days. Preoperative measurements showed excellent reproducibility, and postoperative measurements showed progressive deoxygenation toward the distal aspect of the flap. NIR imaging at $1 \mathrm{~h}$ after flap elevation showed a zone of demarcation that corresponded with that noted clinically at $72 \mathrm{~h}$.

In the acute study $(\mathrm{n}=3)$, NIR spectroscopy, imaging and laser Doppler flowmetry were acquired before, immediately following and $1 \mathrm{~h}$ after raising the flap, and then measurements were taken after applying a vascular clamp across the base of the flap; reperfusion was evaluated after clamp release. Spectroscopy immediately following flap elevation indicated deoxygenation of the most distant part of the flap. Clamping the base of the flap caused deoxygenation of the whole flap; this was immediately evident on both spectroscopy and imaging. These changes recovered after releasing the clamp in the areas that were expected to survive. Laser Doppler flowmetry results generally correlated well with the NIR spectroscopy and imaging results. However, the method was very sensitive to fine movements during monitoring. The main advantage of NIR monitoring is that it looks directly at oxygen consumption rather than measuring blood flow. In addition, the NIR imaging gives a global picture of the eventual fate of the flap. These properties make these devices much more practical when the flap's well-being is concerned.

Key Words: Blood flow in flaps; Flap failure; Monitoring tissue viability; Oxygenation of flaps

Nouvelle approche dans l'évaluation des lambeaux non viables à l'aide de la spectroscopie et de l'imagerie dans le proche infrarouge

RÉSUMÉ: Les méthodes d'évaluation de la viabilité des tissus devraient se diviser en deux catégories : celles qui mesurent le débit sanguin et celles qui surveillent le métabolisme tissulaire. Le problème avec la mesure du débit sanguin, c'est que les résultats obtenus peuvent être trompeurs en raison du phénomène des échanges artério-veineux. La spectroscopie dans le proche infrarouge (SPI) permet de visualiser certaines molécules dans les tissus. On a montré, dans la présente étude, à l'aide de lambeaux cutanés renversés de rats McFarlane, le transport de l'oxygène dans les tissus le long du lambeau, sous forme de spectre; pour ce faire, on s'est servi de l'absorption différentielle de l'oxyhémoglobine et de la désoxyhémoglobine à des longueurs d'onde variant entre $650 \mathrm{~nm}$ et $900 \mathrm{~nm}$. L'imagerie dans le proche infrarouge (IPI) fonctionne suivant le même principe, mais elle fournit plutôt une image de la saturation en oxygène, les zones les

voir page suivante

\footnotetext{
Presented at the American Society of Plastic and Reconstructive Surgeons/Plastic Surgery Educational Foundation/American Society of Maxillofacial Surgeons 67th Annual Scientific Meeting in Boston, Massachusetts, October 3 to 7, 1998

Presented in part at the Canadian Society of Plastic Surgeons' 52nd Annual Meeeting in Victoria, British Columbia, May 20 to 23, 1998

The paper won a prize at the 1997 Annual Meeting of the American College of Surgeons' Manitoba Chapter, Winnipeg, Manitoba

Correspondence and reprints: Dr Badr Abdulrauf, Section of Plastic Surgery, Room GC413, Health Sciences Centre, 820 Sherbrook Street, Winnipeg, Manitoba R3A 1R9. Telephone 204-787-1485, fax 204-787-4837
} 
plus sombres des lambeaux correspondant aux régions les moins oxygénées, et inversement. On a mené deux types d'étude. Dans l'étude en phase chronique $(n=10)$, la peau intacte a été soumise, pendant trois jours avant l'intervention, à la SPI, et il en a été de même après le relèvement du lambeau, en divers endroits. Les mesures prises en phase préopératoires montrent une excellente reproductibilité, et les mesures prises en phase postopératoires révèlent une désoxygénation progressive vers la partie distale du lambeau. L'IPI effectuée $1 \mathrm{~h}$ après le relèvement du lambeau a décelé une zone de démarcation qui s'est finalement avérée correspondre à celle qui a été observée cliniquement au bout de 72 heures.

Dans l'étude en phase aiguë $(\mathrm{n}=3)$, on a eu recours à la spectroscopie et à l'imagerie dans le proche infrarouge ainsi qu'à la débitmétrie Doppler au laser avant, immédiatement après et 1 heure après le relèvement du lambeau; des mesures ont également été prises après la pose d'un clamp vasculaire à la base du lambeau, et après son retrait pour en évaluer la reperfusion. La SPI effectuée immédiatement après le relèvement du lambeau a décelé un phénomène de désoxygénation dans la partie la plus distale du lambeau. La pose du clamp vasculaire à la base du lambeau a provoqué une désoxygénation généralisée, et ses effets ont été perçus immédiatement à la spectroscopie et à

l'imagerie. Après le retrait du clamp, les changements observés sont disparus dans les zones viables. Les résultats de la débitmétrie Doppler au laser correspondent bien, en général, à ceux de la SPI et de l'IPI. Toutefois, la méthode s'est avérée très sensible aux déplacements fins durant la surveillance. Le principal avantage de la technologie dans le proche infrarouge réside dans la surveillance de la consommation d'oxygène plutôt que dans le débit sanguin. En outre, l'IPI donne une image globale du sort possible du lambeau. Ces propriétés rendent ces appareils beaucoup plus pratiques dans les cas où la viabilité du lambeau est en jeu.

$\mathrm{I}_{\mathrm{t}}^{\mathrm{n}}$ n spite of continued efforts over many decades, an objective method of early, reliable assessment of flap viability has not been found. Use of pharmacological agents, vital dyes, radioisotopes, laser flow evaluation and many other modalities have been tried and found to be lacking (1). To date, clinical assessment based on observation of colour, temperature and capillary perfusion remains the most practical and reliable method of monitoring the well-being of the flap. Unfortunately, clinically observable changes are gradual in onset and open to individual bias, and may become evident when it is too late to salvage tissues.

Infrared spectroscopy is the study of the interaction of infrared radiation with matter. The near infrared (NIR) region of the electromagnetic spectrum is considered to lie in the wavelength range of $700 \mathrm{~nm}$ to $2500 \mathrm{~nm}$, where the spectra of some of the important molecules such as oxy- and deoxyhemoglobin lie. NIR spectroscopy depends on the ability of NIR light to penetrate tissues, inducing an electronic transition. A spectrum is obtained by measuring the light that is reflected by the tissues. Deoxyhemoglobin is maximally absorbed at $760 \mathrm{~nm}$ and oxyhemoglobin at $900 \mathrm{~nm}$. The absorption coefficients of the two are equal at $800 \mathrm{~nm}$ (an isobestic point). Therefore, hemoglobin oxygen saturation can be obtained by taking the ratio of light attenuation at $800 / 760 \mathrm{~nm}$.

In the present article, it is demonstrated that a simple, two-wavelength oximetry algorithm that uses wavelengths centred on the NIR absorption of deoxyhemoglobin can be used to generate images that are sensitive to the degree of oxygenation of the imaged tissues. Both NIR spectroscopy and imaging can detect inadequate tissue oxygenation before overt clinical signs arising from poor perfusion.

\section{ANIMALS AND METHODS}

\section{Experimental model}

This study was done using 13 male Sprague Dawley rats weighing between $350 \mathrm{~g}$ and $450 \mathrm{~g}$. General anesthesia was administered to all animals before preparation, monitoring and surgery. The dorsal surface of each rat was shaved two

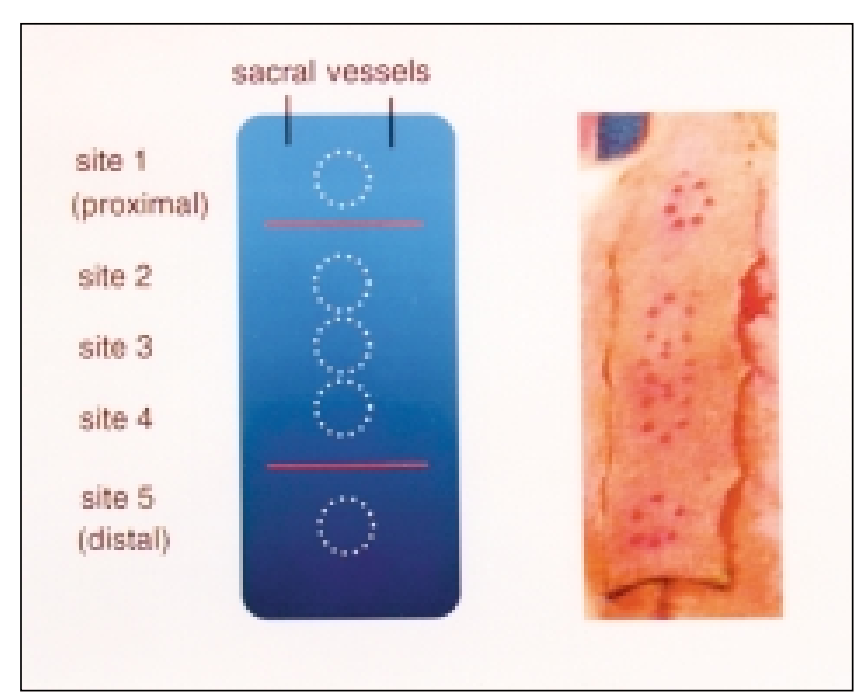

Figure 1) Reverse McFarlane flap with monitoring sites marked on the dorsum of the rat

days before the onset of preoperative measurements. Full physiological monitoring of pulse, blood pressure, temperature, blood gases and electrolytes was maintained throughout the experiment. All the parameters monitored were within the normal range.

Reproducible, $310 \mathrm{~cm}$, caudally based flaps and monitoring sites were marked on the dorsum of each animal by using a silastic template. The flap was raised, and the triangular graft was harvested from the cranial end of the dorsum. The donor site was closed by using the graft at the base. The flap was expanded to its original size where it was held with sutures (2) (Figure 1).

\section{NIR spectra}

A near infrared spectroscopy systems 6500 (Perstop, Silver Springs, Maine) spectrometer, with a custom bifurcated fibreoptic bundle (Ceram Optic, Enfield, Connecticut) was used to collect the NIR spectra. To convert the raw data into 


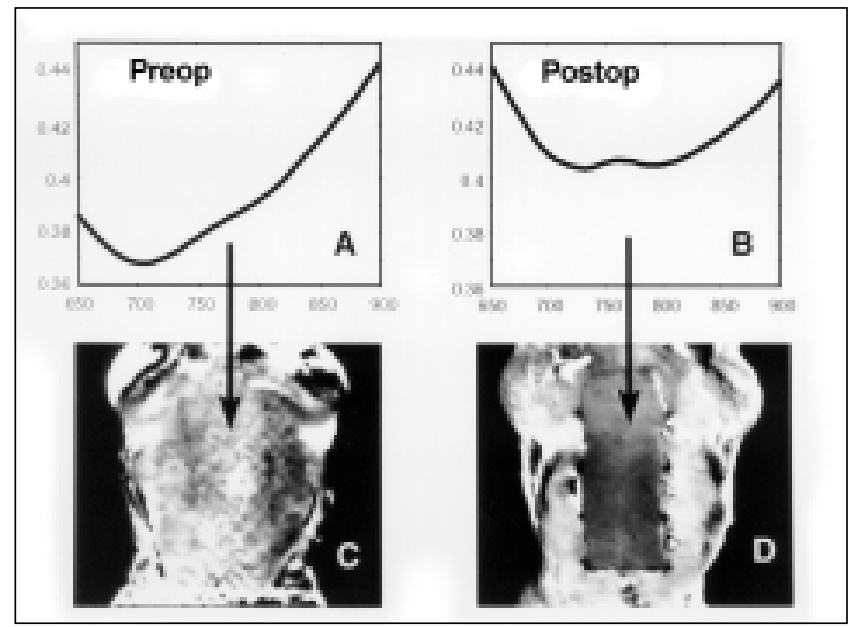

Figure 2) A,B Mean near infrared spectra collected at site 3 over a $72 \mathrm{~h}$ pre- (Preop) and $72 \mathrm{~h}$ postoperative (Postop) monitoring period are compared. The spectrum of the $760 \mathrm{~nm}$ wavelength channel is shown. C,D The oxygen saturation images of the same flap, acquired before and after surgery

reflectance spectra, a Spectralon reflectance standard (Lab Sphere, North Sutton, New Hampshire) was used. To produce each reflectance spectrum, 64 scans were collected between $650 \mathrm{~nm}$ and $900 \mathrm{~nm}$ at a resolution of $10 \mathrm{~nm}$.

The level of deoxyhemoglobin is a good indicator of the oxygenation of tissues. It can best be monitored by observing the changes in the spectrum at $760 \mathrm{~nm}$.

\section{Images}

A Photometrics Series 200 charge-coupled device camera (with a Nikon Macro AF60 lens, Nikon, Melville, New York) and a Cambridge Research Instrument liquid crystal tunable filter (Cambridge Research Instruments Inc, Boston, Massachusetts) were used to gather the NIR images at $760 \mathrm{~nm}$ and $800 \mathrm{~nm}$. Oxygen saturation images were then computed from these two infrared photographs to show the level of tissue oxygenation in the whole flap.

Each image needed a $40 \mathrm{~ms}$ exposure and, as reference, the white side of a Kodak Gray Card (Kodak, Rochester, New York) with a 90\% reflectance was used. Coloured digital photographs were taken during each assessment, both pre- and postoperatively.

\section{Laser Doppler}

A Flolab laser Doppler (Moor Instruments Inc, Wilmington, Delaware) with a bifurcated fibreoptic bundle was used to collect signals in the $780 \mathrm{~nm}$ to $820 \mathrm{~nm}$ range. Every recorded signal was a mean of 30 scans over $30 \mathrm{~s}$. The method uses the Doppler shift principle that moving red blood cells shift the frequency of the incident laser light. The velocity of red blood cells is proportional to the Doppler shift profile. Data were processed to generate information on blood flow.

\section{Chronic study}

The chronic study $(n=10)$ aimed to check the accuracy and the reproducibility of the results. Five sites were monitored

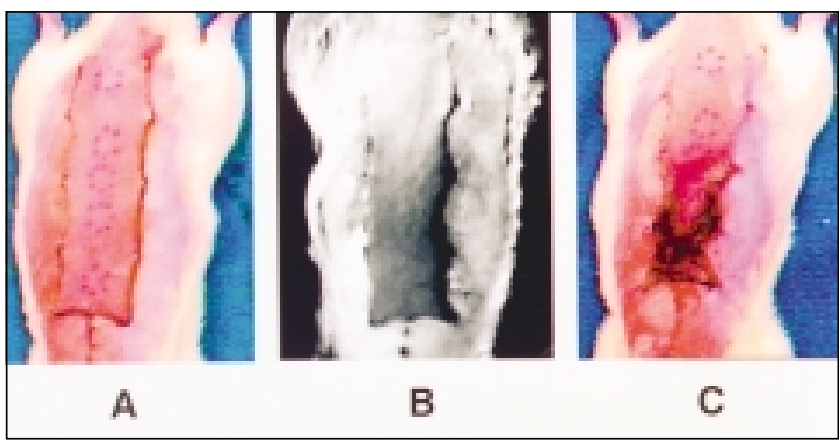

Figure 3) A Clinical appearance of the flap $1 \mathrm{~h}$ after elevation. B Appearance of near infrared image taken $1 \mathrm{~h}$ after surgery. $\mathbf{C}$ Appearance of the same flap $72 \mathrm{~h}$ later

on the dorsum of the rat before surgery and later along the flap. The spectroscopic data, consisting of three NIR measurements, were acquired for each site for every time point; these were collected every $6 \mathrm{~h}$ for $72 \mathrm{~h}$ before and after flap elevation. Only some of these results are presented because the rest were the subject of a previous publication (2). The NIR images were compared with the photographs of the flap taken $72 \mathrm{~h}$ postoperatively.

\section{Acute study}

The objective of the acute study $(\mathrm{n}=3)$ was to monitor tissue oxygenation following flap ischemia and reperfusion. NIR spectra, images and the laser Doppler data were acquired before, immediately following and $1 \mathrm{~h}$ after raising the flap. A $3 \mathrm{~cm}$ long vascular clamp was then applied across the base of the flap. Further data were collected after 5, 20 and 40 mins of ischemia. The clamp was removed after 50 mins, and measurements were taken after 5, 20, 40, 120 and 180 mins of reperfusion.

\section{Chronic study}

\section{RESULTS}

Before surgery, spectral curves obtained from all five sites of the dorsum of each rat showed normal tissue oxygenation, with excellent reproducibility in all animals and sites. Postoperatively, the tissue oxygenation varied. Site 1 remained viable and well oxygenated throughout the study period. Site 5, in all animals, rapidly deoxygenated; early cyanosis appeared within $6 \mathrm{~h}$ and progressed to necrosis with desiccation by $72 \mathrm{~h}$. Deoxygenation and cyanosis increased from site 2 to site 5 . The eventual outcome at site 3 was variable, but necrosis occurred in most flaps.

Comparison of graphs A and B of Figure 2 show the changes of the NIR spectra obtained at site 3 before and after the raising of the flap. Graph B shows a peak at $760 \mathrm{~nm}$, indicating an increase of deoxyhemoglobin in the tissues at this site.

The NIR image $\mathrm{C}$ (Figure 2) shows the dorsum of the rat preoperatively. It is uniformly grey, indicating that the oxygen content of the tissues is normal. Image D (Figure 2), taken $1 \mathrm{~h}$ after the elevation of the flap, already shows the development of a dark zone in the distal two-thirds of the 


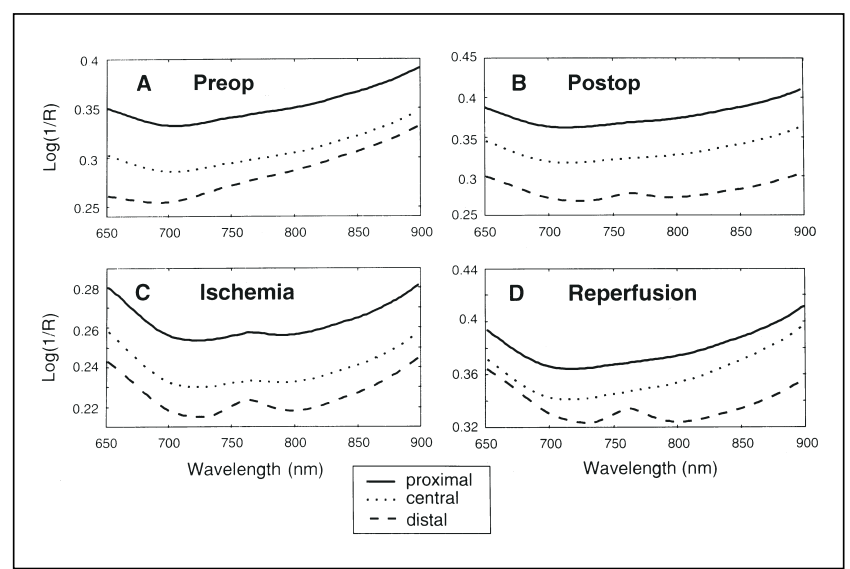

Figure 4) Near infrared spectra at the proximal, central and distal sites are compared before and $1 \mathrm{~h}$ after surgery $(A, B)$, as well as during ischemia and reperfusion $(C, D)$

flap, implying a decrease in the oxygen content of the tissues.

A colour photograph of the flap taken $1 \mathrm{~h}$ postoperatively showed no evidence of hypoxia (Figure 3A). The NIR image taken at the same time already indicated that the flap was in trouble (Figure 3B). The extent of the necrosis as seen at $72 \mathrm{~h}$ (Figure $3 \mathrm{C}$ ) corresponds very closely to the NIR image taken at $1 \mathrm{~h}$.

\section{Acute study}

The results of the acute study are shown in Figure 4. Graph A, representing the NIR spectra at sites 1,3 and 5 before the flap was raised, shows curves reflecting the same degree of oxygenation. Graph B, after the raising of the flap, shows peaks at $760 \mathrm{~nm}$ at site 5, indicating deoxygenation. Graph C, after the clamp was applied across the base of the flap, shows a peak at $760 \mathrm{~nm}$ at all three sites, as was expected. Graph D, after the clamp was removed, shows the amount of reperfusion after 5 mins. Site 1 is no longer compromised, but site 5 continues to show the deoxyhemoglobin peak at $760 \mathrm{~nm}$. Site 1 remained fully oxygenated in the postoperative period and recovered fully following reperfusion. Closer inspection of the spectra in the postoperative and reperfusion stages revealed a greater degree of hypoxia following reperfusion of site 5 , as evidenced by a more pronounced peak at $760 \mathrm{~nm}$.

The corresponding oxygen saturation images and laser Doppler blood flow measurements are shown in Figures 5 and 6 , respectively. Figure 5A shows greyscale oxygen saturation images of a flap before surgery. As can be seen from Figure 5B, only site 1 appears to be well oxygenated. Following application of the clamp across the base of the flap (Figure 5C), the whole flap darkens, indicating severe hypoxia. After 5 mins of reperfusion, significant recovery is noted in zone 1 only (Figure 5D).

The laser Doppler results are shown in Figure 6. They confirm the findings of both the spectroscopic and imaging studies. Laser Doppler flux at site 1 displayed only a modest

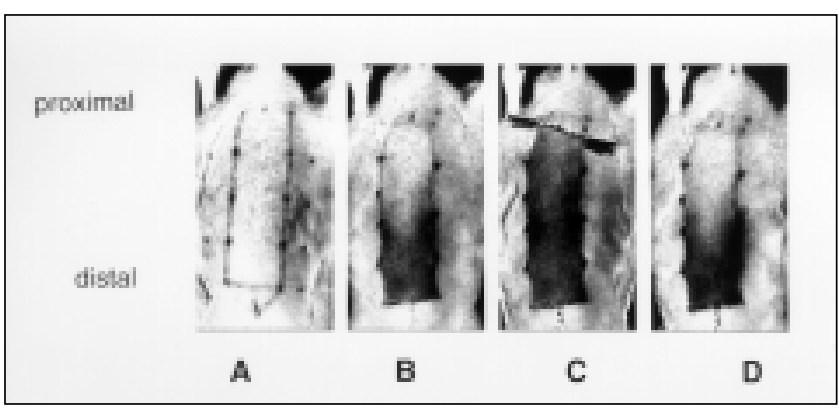

Figure 5) Greyscale oxygen saturation images of a flap before surgery (A), immediately following flap elevation (B), within 5 mins of ischemia (C) and within 5 mins of reperfusion (D)

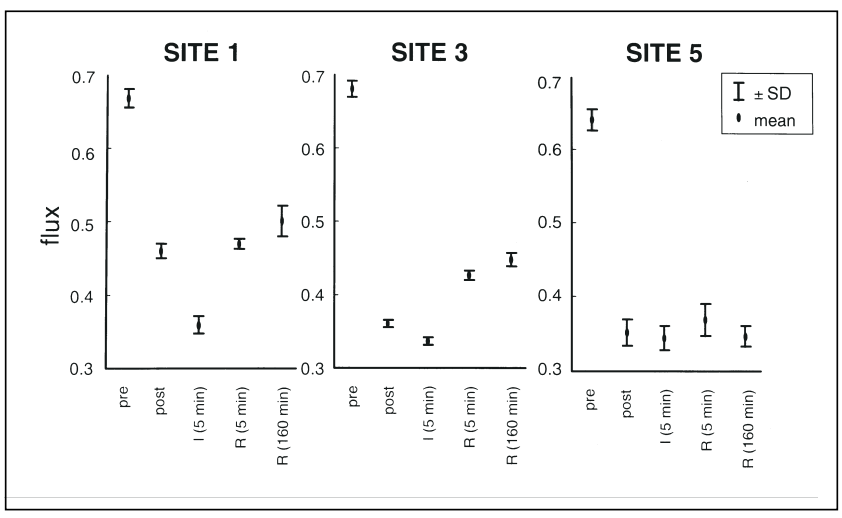

Figure 6) Laser Doppler time course measurements at site 1 (proximal), site 3 (central) and site 5 (distal). Measurements were acquired pre-and postoperatively, as well as during ischemia (I) and reperfusion (R)

drop upon elevation from its pre-elevation value, whereas sites 3 and 5 displayed a marked drop in perfusion. This was consistent with the NIR results presented in graphs A and B of Figures 4 and 5. Laser Doppler flux measurements indicated no change in perfusion at site 5 , either with application of the vascular clamp or upon reperfusion. Laser Doppler was also unable to detect a significant drop in perfusion at site 3 upon ischemia. Conversely, NIR spectroscopy and imaging detected a significant change in oxygenation upon ischemia at site 3 along the flap. Laser Doppler flux at site 3 displayed a hyperemic response upon reperfusion. This hyperemic response was less evident in the NIR findings. The laser Doppler and NIR results coincided for site 1.

\section{DISCUSSION}

Of the many methods available for monitoring skin viability, none has passed the test of time. Original pharmacological methods, dye injection and radioisotope use have either been too inaccurate or too invasive (1). The more modern methods of temperature monitoring are often difficult to interpret and translate into a clinical decision (3). The use of laser Doppler flowmetry has its own problems. Though the technique is noninvasive, it only measures the blood flow within a small volume of tissue. Poor probe placement or movement of the probe leads to poor reproducibility (4). Magnetic resonance spectroscopy is capable of accurately monitoring tissue me- 
tabolism, but it has its drawbacks of prohibitive initial cost and total lack of portability (5).

One of the major advantages of NIR monitoring devices is that they are capable of monitoring tissue oxygen consumption rather than blood flow. In 1974, using isotopes, Reinisch (6) claimed to have demonstrated in a pig model the presence of patent arteriovenous (AV) shunting in the failing part of a pedicled flap. In 1983, Kerrigan (7) repeated the original work by Reinisch on a much bigger scale and concluded that, although AV shunts were present, the flap mainly failed because of arterial insufficiency. Sasaki and Pang (8) showed that the maximum amount of AV shunting occurs about $12 \mathrm{~h}$ postoperatively in a neurovascular skin island flap in a rat model. This may be important in terms of timing of pharmacological interventions (8). In an island rectus abdominis flap in the pig, Hjortdal et al (9) demonstrated that AV shunting accounted for $50 \%$ of total blood flow, and concluded that there was a need for direct monitoring of nutrition in the tissues, rather than measuring blood flow. In addition to these experiments, Weinzweig and Gonzalez (10) presented clinical examples of free flaps that had died gradually between $4 \mathrm{~h}$ to 6 weeks postoperatively in spite of a strong Doppler tone. They suggested that microemboli formed at the arterial anastomosis and caused shunting of the microcirculation (10).

It is clear that significant controversy exists as to the presence and importance of AV shunts. Thus, any method of assessing viability purely using blood flow studies can give fallacious results. The NIR monitoring devices overcome this problem by evaluating tissue oxygenation at the cellular level. This accurate assessment of tissue viability will prove to be important not only in the monitoring of flaps, but also in estimating the depth of burns, the severity of frostbites and the circulatory status of compromised digits or limbs.

The information obtained by the oxygen saturation NIR images, globally showing the fate of the whole flap and delineating the exact pattern of demarcation and the sensitivity to secondary ischemia and reperfusion, cannot be obtained by any other monitoring tool. This proves the old phrase 'a picture is worth a thousand words'.

The Thorniley group (11) did a lot to develop and demonstrate the potential uses of NIR spectroscopy, but similar to our earlier results (2), this method failed to give a global picture of flap oxygenation, which NIR imaging is able to do rapidly, reliably and noninvasively.

\section{CONCLUSIONS}

It is clear that the NIR spectroscopy and imaging show promise in monitoring a failing flap. The results to date have been very consistent and easily reproducible, and the investigation is totally noninvasive. Acquisition of signals was rapid and imaging was equally so. The laser Doppler flowmetry produced comparable results; however, the method was very sensitive, and inadvertent movements led to false readings. We believe that NIR spectroscopy will prove to be clinically reliable, portable and relatively inexpensive. A system to generate NIR images of tissues under investigation will be more expensive.

ACKNOWLEDGEMENTS: The authors acknowledge the Firefighters Burn Fund, Inc of Manitoba for a grant to support this research and thank Ms Linda Mydynski for her help in preparing this manuscript.

\section{REFERENCES}

1. Furnas H, Rosen JM. Monitoring in microvascular surgery. Ann Plast Surg 1991;26:265-72.

2. Stranc MF, Sowa MG, Abdulrauf B, Mantsch HH. Assessment of tissue viability using near-infrared spectroscopy. Br J Plast Surg 1998;51:210-7.

3. Kaufman T, Granick MS, Hurwitz DJ, Klain M. Is experimental muscle flap temperature a reliable indicator of its viability? Ann Plast Surg 1987;19:34-41.

4. Heden P, Jurell G, Arnander C. Prediction of skin flap necrosis: a comparative study between laser Doppler flowmetry and fluorescein test in a rat model. Ann Plast Surg 1986;17:485-8.

5. Cheung A, Zhong J, Gore JC, Cuono CB. Localized in vivo ${ }^{31} \mathrm{P}$ NMR spectroscopy of skin flap metabolism. Magn Reson Med 1994;32:572-8.

6. Reinisch JF. The pathophysiology of skin flap circulation: The delay phenomenon. Plast Reconst Surg 1974;54:585-98.

7. Kerrigan CL. Skin flap failure: Pathophysiology. Plast Reconstr Surg 1983;72:766-77.

8. Sasaki GH, Pang CY. Hemodynamics and viability of acute neurovascular island skin flaps in rats. Plast Reconstr Surg 1980;65:152-8.

9. Hjortdal VE, Hansen ES, Kjolseth D, Henriksen TB, Gottrup F, Djurhuus JC. Arteriovenous shunting and regional blood flow in myocutaneous island flaps: An experimental study in pigs. Plast Reconstr Surg 1991;87:326-34.

10. Weinzweig N, Gonzalez M. Free tissue failure is not an all-or-none phenomenon. Plast Reconstr Surg 1995;96:648-60.

11. Thorniley MS, Sinclair JS, Barnett NJ, Shurey CB, Green CJ. The use of near-infrared spectroscopy for assessing flap viability during reconstructive surgery. Br J Plast Surg 1998;51:218-26. 